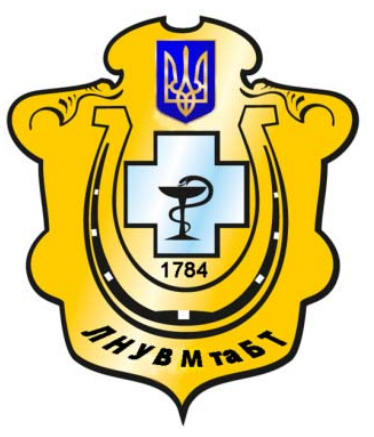

Науковий вісник Львівського національного університету ветеринарної медицини та біотехнологій імені С.3. Гжицького

Scientific Messenger of Lviv National University of Veterinary Medicine and Biotechnologies named after S.Z. Gzhytskyj

doi:10.15421/nvlvet6902

ISSN 2413-5550 print

ISSN 2518-1327 online

$\underline{\text { http://nvlvet.com.ua/ }}$

УДК 502.33:631.15

\title{
Еколого-економічні особливості створення і розвитку Вінницької птахофабрики за принципами «аграрного ренесансу»
}

\author{
I.В. Власенко \\ vlasenkovanya@mail.ru
}

\begin{abstract}
Вінницький торговельно-економічний інститут Київського начіонального торговельно-економічного
\end{abstract} університету, вул. Соборна, 70, м. Вінниця, 21050 Украӥна

Відродження аграрної сфери справедливо пов'язують із становленням високотехнологічного, конкурентоспроможного $i$ прибуткового аграрного сектору, формуванням нової організаційної структури сільського господарства та його ринкової інфраструктури. Водночас ие відродження передбачає також подолання сочіального занепаду села.

Для ивого пропонуємо механізми саначії аграрного землекористування проводити за приниипами «аграрного ренесансу». Використовуючи таку організачійно-правову форму ведення бізнесу, агрохолдинги активно залучають капітал через випуск і розміщення акиій на фондових біржах за кордоном, чого не можуть собі дозволити інші форми агробізнесу.

У результаті капіталізації сільського господарства за домінуючим напрямом вливання капіталу в галузь з інших сфер економіки виникли господарські формування нового типу, які зовсім не були притаманні вітчизняній практиці. Тому на сучасному етапі існує нагальна потреба дослідження питання сучасної моделі вітчизняного розвитку сільського господарства, визначення місия агропромислових формувань нового типу в контексті еколого - економічного землекористування агросфери. У результаті досліджень встановлено, що однією з причин негативної ситуації в агросфері є обмежена можливість прачевлаштування сільського населення. Механізми санації, перспективного розвитку агросфери залишаються маловивченими. Запропоновано нову політика санації агросфери, яка повинна концентруватися навколо трьох головних осей: а) конкурентоспроможність б) відновлення земельних ресурсів в) багатофункиіональне село і якість життя на селі. Для иього пропонусмо механізми санаиї аграрного землекористування проводити за принципами «аграрного ренесансу». Впроваджується принии аграрного ренесансу - сочіально-економічного відродження або «економічних майданчиків розвитку територій», стають своєрідними «точками економічного зростання» аграрної економіки, оскільки саме їм вдається освоїти занедбані землі. При иьому майданчики з вирочування курчат-бройлерів знаходяться в Тростянеиькому та Тульчинському районах поблизу населених пунктів звідки господарство черпає трудові ресурси $i$ проходить соиіальноекономічне відродження села. Всього планується освоїти 26 майданчиків з вирощування курчат-бройлерів на 33,8 млн. курей-бройлерів. Впровадження сучасних технологій виробництва м'яса птиџі дозволило підвищити конкурентоспроможність, часткового відродження якості життя на селі і вдалося раціонально освоїти місцеві земельні ресурси.

Ключові слова: кури-бройлери, виробництво м'яса, економічні майданчики, трудові ресурси, птиця, соціальноекономічне відродження села

\section{Эколого-экономические особенности создания и развития Винницкой птицефабрики по принципу «аграрного ренессанса»}

\author{
И.В. Власенко \\ vlasenkovanya@mail.ru
}

Винницкий торгово-экономический институт Киевского национального торгово-экономического университета, ул. Соборная, 70, Винница, 21050, Украина

\footnotetext{
Citation:

Vlasenko, I. (2016). Environmental and economic features creation and development of the Vinnitsa poultry farms on the principle of «agricultural renaissance». Scientific Messenger LNUVMBT named after S.Z. Gzhytskyj, 18, 2(69), 9-12.
} 
Возрождение аграрной сферы справедливо связывают со становлением высокотехнологичного, конкурентоспособного и прибыльного аграрного сектора, формированием новой организационной структуры сельского хозяйства и его рыночной инфраструктуры. В то же время это возрождение предполагает также преодоление соииального упадка села.

Для этого предлагаем механизмы санации аграрного землепользования проводить по принципу «аграрного ренессанса». Используя такую организационно-правовую форму ведения бизнеса, агрохолдинги активно привлекают капитал посредством выпуска и размещения акиий на фондовых биржах за рубежом, чего не могут себе позволить другие формы агробизнеса. В результате капитализации сельского хозяйства по доминирующим направлением вливания капитала в отрасль из других сфер экономики возникли хозяйственные формирования нового типа, которые вовсе не были присущи отечественной практике. Поэтому на современном этапе существует необходимость исследования вопроса современной модели отечественного развития сельского хозяйства, определения алкоголизма нового типа в контексте эколого- экономического землепользования агросферы. В результате исследований установлено, что одной из причин негативной ситуаиии в агросфере является ограниченная возможность трудоустройства сельского населения. Механизмь санации, перспективного развития агросферы остаются малоизученными. Предложена новая политика санации агросферы, которая должна концентрироваться вокруг трех главных осей: а) конкурентоспособность б) восстановление земельных ресурсов в) многофункииональное село и качество жизни на селе. Для этого предлагаем механизмы санации аграрного землепользования проводить по принциипу «аграрного ренессанса». Внедряется принцип аграрного ренессанса - соичильно-экономического возрождения или «экономических площадок развития территорий», становятся своеобразными "точками экономического роста» аграрной экономики, поскольку именно им удается освоить заброшенные земли. При этол площзадки по выращчиванию изыплят-бройлеров находятся в Тростянецком и Тульчинском районах вблизи населенных пунктов откуда хозяйство черпает трудовые ресурсы и проходит социально-экономическое возрождение села. Всего планируется освоить 26 площадок по выращиванию цыллят-бройлеров на 33800000. кур-бройлеров. Внедрение современных технологий производства мяса птицы позволило повысить конкурентоспособность, частичного возрождения качества жизни на селе и удалось рачионально освоить местные земельные ресурсы.

Ключевые слова: куры-бройлеры, производство мяса, экономические площчадки, трудовые ресурсы, птица, социиалноэкономическое возрождение села

\title{
Environmental and economic features creation and development of the Vinnitsa poultry farms on the principle of «agricultural renaissance»
}

\author{
I. Vlasenko \\ vlasenkovanya@mail.ru
}

\begin{abstract}
Vinnitsa Trade and Economic Institute of Kyiv National University of Trade and Economics,
\end{abstract} Cathedral Str., 70, Vinnitsa, 21050, Ukraine

The revival of the agricultural sector is rightly associated with the development of high-tech, competitive and profitable agricultural sector, formation of new organizational structure and its agricultural market infrastructure. However, this revival also involves overcoming of social decline of the village.

For this propose mechanisms of reorganization of the agricultural land to carry out the principles of «agricultural renaissance». While using such legal form of business, agricultural holdings actively raising capital through the issuance and placement of shares on foreign stock exchanges, which can not afford other forms of agribusiness.

As a result of the capitalization of agriculture enterprizes dominant direction for capital injections into the industry from other sectors of the economy are having a new type of business that were not inherent in domestic practice. Therefore, at present there is an urgent need to study the issue of domestic modern model of agriculture, agro-industrial units determine where in the context of a new type of eco-economic agrosphere land.

The studies found that one cause of the negative situation in the agricultural domain is the limited employment opportunities in rural areas. Restructuring, future development of agrosphere remain poorly understood. The new policy in agrosphere reorganization should focus around three main aspects: a) competitiveness b) restoration of land resources) the rich countryside and the quality of life in rural areas. For this purpose the mechanisms of reorganization of the agricultural land to carry out the principles of «agricultural renaissance» was established. It is introduced the principle of agrarian renaissance - socio-economic recovery or "economic areas of the territories» become a kind of "points of growth» for agrarian economy, since they are able to master the abandoned land. This ground for growing broiler chickens are Trostyanetskiy and Tulchyn areas near localities where farm labor draws and passes socio-economic revival of the village. It is planned to master 26 sites for growing broiler chickens at 33.8 million broilers. The introduction of modern technologies of poultry allowed to increase competitiveness, as a partial revival rural life and managed efficiently learn the local land resources. lage

Key words: chickens Broilers meat production, economic grounds, human resources, poultry, socio-economic revival of the vil-

\section{Вступ}

В даний час у світовій та вітчизняній практиці однією 3 ефективних форм міжгалузевої інтеграції $\epsilon$ агропромислові формування холдингового типу, що об'єднують весь цикл просування товарної продукції від сільгоспвиробництва, промислової переробки до кінцевої реалізації продовольчих товарів, що дозволяє знизити міжгосподарські та міжгалузеві витрати, отримати додаткові доходи і забезпечити рентабельність суспільного виробництва. Використовуючи таку організаційно-правову форму ведення бізнесу, агрохолдинги активно залучають капітал через випуск i розміщення акцій на фондових біржах за кордоном, 
чого не можуть собі дозволити інші форми агробізнеcy.

У результаті капіталізації сільського господарства за домінуючим напрямом вливання капіталу в галузь 3 інших сфер економіки виникли господарські формування нового типу, які зовсім не були притаманні вітчизняній практиці. Тому на сучасному етапі існує нагальна потреба дослідження питання сучасної моделі вітчизняного розвитку сільського господарства, визначення місця агропромислових формувань нового типу в контексті еколого - економічного землекористування агросфери.

Значний внесок у дослідження питань економічних інтересів і вирішення окремих соціальних питань, що виникли у процесі проведення земельної реформи, здійснили такі вітчизняні вчені (Azizov et al., 2001; Vlasenko, 2007; Bohira, 2008; Bojko, 2008; Ambrosov, 2011; Kolot and Grishnova, 2012).

Тому на сучасному етапі існує нагальна потреба визначення місця агропромислових формувань нового типу в контексті еколого- економічного землекористування агросфери.

Метою статі є аналіз сучасної моделі агропромислових формувань нового типу в контексті еколого економічного розвитку птахівництва регіону.

\section{Результати та їх обговорення}

Відродження аграрної сфери справедливо пов'язують із становленням високотехнологічного, конкурентоспроможного і прибуткового аграрного сектору, формуванням нової організаційної структури сільського господарства та його ринкової інфраструктури. Водночас це відродження передбачає також подолання соціального занепаду села.

Для цього пропонуємо механізми санації аграрного землекористування проводити за принципами «аграрного ренесансу».

Проведені дослідження у Вінницькій області показують, що «Миронівський хлібопродукт» інвестував 1,5 млрд. доларів до 2015 року у створення ТОВ «Вінницька птахофабрика». Сучасна структура ТОВ «Вінницька птахофабрика» побудована на основі горизонтальної інтеграції та концентруватися довкола трьох головних осей:

а) конкурентоспроможність;

б) відновлення земельних ресурсів;

в) багатофункціональне село та якість життя на селі.

Компанія побудувала виробничий комплекс, що складається з птахофабрики потужністю 420 тис. тонн м'яса на рік, комбікормового заводу потужністю 1,2 млн. тонн продукції на рік, олієекстракційного заводу потужністю переробки 500 тис. тонн соняшнику на рік, ріпакоекстракційного заводу потужністю 350 тис. тонн в рік, 9 елеваторів загальною потужністю прийому зернових і олійних більше 1 млн. куб. м, та 26 майданчиків вирощування бройлерів на 33,8 млн. курей-бройлерів, інкубатор на $300-350$ млн. яєць, забійного заводу і заводу з виробництва готових м'ясних виробів. «Миронівський хлібопродукт» вже запустив в експлуатацію першу чергу будівництва птахо- комплексу, завдяки чому вдалося до певної міри економічно оздоровити аграрні сільські території.

В результаті досліджень встановлено, що особливістю створення агропромислового об'єднання $\epsilon$ те, що впроваджується принцип аграрного ренесансу соціально-економічного відродження або «економічних майданчиків розвитку територій». Філія «Птахокомплекс» юридично розташована у м. Ладижин, але територіально майданчики по вирощуванню курчатбройлерів знаходяться у Тростянецькому та Тульчинському районах поблизу населених пунктів звідки господарство черпає трудові ресурси та проходить соціально-економічне відродження села. Всього планується освоїти 26 майданчиків по вирощуванню курчат-бройлерів. При підлоговому вирощуванні бройлерів використовується не типовий пташник 3

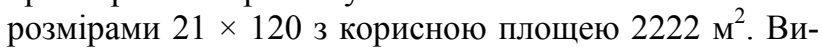
рощування бройлерів здійснюється крупними одновіковими партіями в пташниках на підлозі з використанням глибокої підстилки. Для підстілки використовують відходи олієекстракційного заводу - соняшникову лузгу (лушпиння). При щільності посадки 18 голів на $1 \mathrm{~m}^{2}$ площі приміщення їх місткість складає відповідно 40000 тис. голів. Термін вирощування становить 6 тижнів. Тривалість профілактичної перерви складає два тижні. Загальне число днів, необхідне для вирощування бройлерів однієї партії і профілактичної перерви визначається як сума днів, затрачених на вирощування партії бройлерів разом з профілактичною перервою. Після закінчення терміну вирощування 3 приміщення видаляють глибоку підстилку 3 пташника, складують для біологічного знезараження і використовують як органічне добриво на поля, що покращує еколого-економічне аграрне використання земель. На цих землях вирощоють корма для птиці і отримують еколого чисту продукцію - м'ясо птиці. Вінницька птахофабрика отримала дозвіл на експорт курятини в СС (Аграрний ринок>18.11.2014), що, безумовно позитивно вплинуло і на якість їх продукції і на фінансові результати їх діяльності. Ця птахофабрика найбільша не лише в Україні, за обсягами виробництва м'ясної продукції вона найпотужніша в Свропі. Слід зазначити, що на підприємстві використані сучасні передові технології по вирощуванню курчат-бройлерів та виготовленню екологічно чистої курятини. Динаміка розвитку ТОВ «Вінницька птахофабрика» передбачає охопити 70 тис. га сільськогосподарських угідь для комплексу, який розташовуватиметься на землях Гайсинського, Тростянецького і Тульчинського районів. Буде додатково працевлаштовано 1750 людей. Впровадження сучасних технологій виробництва м'яса птиці дозволило підвищити конкурентоспроможність продукції, часткового відродження якості життя на селі та вдалося раціонально освоїти місцеві земельні ресурси. По суті, майданчики вирощування бройлерів стають своєрідними «точками економічного росту» аграрної економіки, бо саме їм нерідко вдається освоїти покинуті землі.

Аналізуючи економічні показники слід зазначити, що основну частину виробничих витрат тваринництва (птахівництва) складає вартість кормів, яка в сучасних умовах дорівнює $60-65 \%$ від загальних витрат. На 
частку інших припадає $35-40 \%$.

Собівартість це відношення загальних витрат до виходу продукції. Валовий прибуток визначаємо шляхом множення валової продукції на ціну.

Різниця між валовим прибутком i загальними витратами визначає чистий прибуток.

Визначаємо рівень рентабельності як процентне відношення чистого прибутку до собівартості реалізованої продукції.

Знаючи валове виробництво м'яса на птахофабриці (440 тис. тонн) знаходимо добуток його та ціни (2500 грн. за 1 центнер) отримуємо суму валового прибутку:

4400000 ц $\times 2500=11000000000$ грн.

Оскільки загальна потреба в комбікормі складає 953 333,3 тонн то витрати на корми при ціні 1 тонни комбікорму в 2000 грн. становитимуть :

953333,3 тонн $\times 2000=1906666600$ грн.

Загальні витрати визначаємо, виходячи із того, що iз загальних витрат 65\% припадає на корми. Отже:

$1906666600 \quad 65 \%$

X $100 \%$

Загальні витрати складуть (1906 666 600 × 100 : 65) = 2933333231 грн.

Собівартість 1 ц продукції знаходимо шляхом ділення загальних витрат на валове виробництво:

$2933333231: 4400000$ ц = 666,6 грн.

Віднімаючи від валового доходу загальні витрати, отримуємо чистий прибуток:

$110000000002933333231=8066666769$ грн.

Рівень рентабельності складе:

$8066666769: 2933333231 \times 100=275 \%$.

Таким чином, при використанні екологоекономічного аграрного ренесансу на затрачену 1 гривню отримуємо 2,75 гривні прибутку.

Відповідно до концепції «економічні майданчики розвитку сільських територій» урізноманітнюються і заходи їх підтримки. Поряд з традиційними механізмами стимулювання розвитку проблемних територій на кшталт грантів, субсидій, цільових програм розвитку, тепер важлива роль відводиться заходам, спрямованим на активізацію внутрішніх ресурсів сільських територій. Йдеться про стимулювання підприємницької діяльності на селі, посилення територіальної мобільності населення, інфраструктурної забезпеченості сільської місцевості, іiі конкурентоздатності та інвестиційної привабливості.

\section{Висновки}

Створення «економічних майданчиків розвитку сільських територій» можна вважати ренесансом сільськогосподарського виробництва, що до певної міри дасть можливість оздоровити депресивні аграрні території, підвищити технічний рівень аграрного виро- бництва, запровадити досконаліший менеджмент, створити нові робочі місця, відвести загрозу банкрутства, що завжди супроводжується негативними соціальними наслідками. Тому приплив капіталу із зовнішніх джерел відігравав і продовжує відігравати в більшості випадків позитивну роль у розвитку сільського господарства на депресивних територіях. Цей процес повинен бути економічно врегульованим i відповідним чином контрольованим. Для цього необхідно створити фінансово-кредитний механізм, адекватний сучасним умовам і цілям підвищення рівня продовольчої безпеки держави.

Перспективи подальших досліджень. Перспективами подальших досліджень $є$ удосконалення системи високотехнологічного, конкурентоспроможного і прибуткового аграрного сектору, формуванням нової організаційної структури сільського господарства та його ринкової інфраструктури. Розв'язання потребують конфлікти інтересів у системі землекористування.

\section{Бібліографічні посилання}

Vlasenko, I.V. (2007). Stymuliuvannia diialnosti pidpryiemnytstva $\mathrm{v}$ depresyvnykh administratyvnykh raionakh Vinnychchyny. Visnyk Khmelnytskoho natsionalnoho universytetu (Ekonomichni nauky). Khmelnytskyi. 2, 66-70 (in Ukrainian).

Vlasenko, I.V. (2013). Rynkovi umovy ahrarnoho hospodariuvannia ta rozvytok silskykh terytorii Ukrainy. Innovatsiina ekonomika. 2(40), 106-110 (in Ukrainian).

Azizov, SM. Keniiskyi, P.K., Skupyi, B.M. (2001). Orhanizatsiia vyrobnytstva i ahrarnoho biznesu v silskohospodarskykh pidpryiemstvakh. K.: IAE, 251252 (in Ukrainian).

Ambrosov, V.Ja. (2011). Perehod k rynochnym zemel'nym otnoshenijam. Strategiï realizaciï zemel'noï reformi. 1, 39-41 (in Russian).

Bohira, M. (2008). Zemelna reforma i stan formuvannia spravzhnikh hospodariv na seli. Zemlevporiad. visn. 2, 37-59 (in Ukrainian).

Bojko, L. (2008). Rozmir zemlekorystuvan' sil'gosppidpryjemstv u systemi chynnykiv efektyvnosti gospodarjuvannja. Zemlevporjad. visn. 6, 63. (in Ukrainian).

Vlasenko, I.V. (2007). Problemy agarnogo pryrodokorystuvannja v rynkovyh umovah gospodarjuvannja : monografija. Vinnycja «Edel'vejs i $\mathrm{K} \gg$ (in Ukrainian).

Kolot, A.M., Grishnova, O.A. (2012). Social'na vidpovidal'ni teorija i praktyka rozvytku : monografija. K.: KNEU (in Ukrainian).

Стаття надійшла до редакиї 19.09.2016 